\title{
Samples of Applied Interdisciplinary Library Lessons
}

\section{Evrim METIN INAL}

evrim@bilkent.edu.tr

İhsan Doğramacı Foundation Private Bilkent Primary and Middle School

School libraries are among the major centers to conduct interdisciplinary studies. Providing the resources and a venue for all subject fields to come together and work collaboratively, school libraries can incorporate library lessons into subject field lesson planning for increased efficiency. This paper presents sample library lessons that are both interdisciplinary and collaboratively prepared. The samples demonstrate how subject field lessons are integrated with library lessons and how students acquire knowledge in these lessons.

Keywords: school librarians, cooperation, object lesson

\section{Introduction}

The library in IB schools in particular has a central place in the programme. The librarian
assumes a key role in the system. They plan collaborative lessons with subject field teachers. These lessons aim to enable students to learn research techniques and enjoy the process. This paper presents samples of interdisciplinary lessons delivered in the library.

\section{"Overcome Obstacles to Gather Information"}

The slogan of the interdisciplinary lesson planned in the framework of the Eco-school project and the PYP unit collaboratively with the Physical Education teacher at Grade 3 level is also the title of the game. The goal of the game is to enable students to learn about the ecological diversity and the food chain through research and enjoy the process in the context of the unit titled "Ecosystem" and the "Eco-school project". The materials required for the lesson are 
research task schedule, color balloons for all students, cones, track equipment, skateboards, boxes, and color cardboard. The activity continued for three weeks in the library and physical education lessons.

In the activity, students are given a research task for the game. For the lesson to be delivered in the planned timeframe, all students must be given the same task. Sample worksheet can be seen below. 


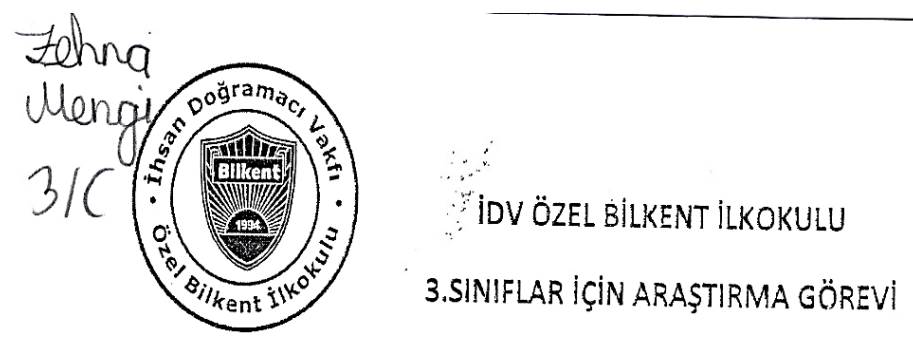

Şuandan itibareh hepiniz birer zoologsunuz yani birer hayvan bilimi uzmanısınız. (:)Gazeteden muhabißr.jer sizinle röportaj için geldiler. Hayvan bilimi uzmanı olarak'da sizden aşağıdaki konular hàkkkinda bilgi rica' ediyorlar.

Sayın hayvan bilimi üzmanımız muhabirlerimize yardımcı olabilir misiniz?

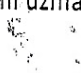

1) Canlıların yaşam alanlarını nerelerdir? Bu yaşam alanlarının isimleri ve özellikleri hakkında bize bilgi verebilir misiniz?

Dünya da, olyanus dibinde 1000 metre deninliginde se denis seucyesind 6000 metre yulebelige tardar uranan, canlibanen yascyabildigi have, top. nal ve su carlebann yasam alanlander. Her canle tïniiniin yasam alane ayn degieldir. Geyileler onmo nda baleblar suda, kangunular aveustunuwyada, belaunat lustar biectete yasanlar. Bu yenter o tunterun yastam

2) Hangi yaşam alanında hangi canlı türleri yaşıyor? Bu konu hakkında bilgi alabilir

Miyiz? Siftlikte yetistribleilen ve yasantumezda yanarlandtgumer hayeanlander. Bunlanín desenda kunt, anslan, Cakal, taplan, tilli gibi ormanlanda yasayan hayearlanda leander. Timsah bale, lunbaga .b. Mlay:

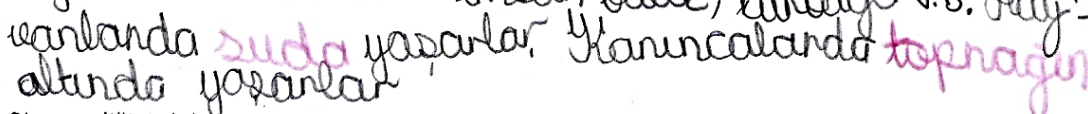

3) Bize verdiğiniz bilgiler ışı̆̆ında sizin seçtiğiniz hayvanlardanen az 10 tanesinin resimini bize getirir misiniz? (Internet, gazete ve dergilerden faydalanabilirsiniz.) Ciecir, at, fil, toueut, lue, adlan, ceylan, köpel, ted,

Not: Bu çalışmayı Beden Eğitimi dersinde yer alacak "Engelleri Aș, Bilgiye Ulaş" oyunu için hazzrlıyoruz. Unele Ödev Teslim Tarihi: 11Şubat -15 Şubat haftası

BEDEN EĞiTiMi

Teşekkür ederiz $:-$

International Association of School Librarianship https://www.iasl-online.org/ 
In the preparation stage, the purpose of the research is explained, and the students are given a research task. Students use the library resources to complete the worksheets. After students are given instructions about how to do research about the topic in the library, they are asked to take notes on the worksheets. Students use books to complete their research, and if there is any information they could not find in the books, then they continue their research on the computer. The last task on the worksheet is assigned to be completed at home. The students can draw animal pictures, cut photographs from newspapers, magazines or other print sources, or take color printouts, based on their preferences, and bring these visuals to school.

The data students have gathered in the research task are evaluated in the library lesson. The visuals students prepared at home are collected and the preparation of the materials for the game starts. In the preparatory stage, the animals shown on the visuals are grouped according to their place in the ecosystem. The pictures/photographs are pasted on cardboards in different colors. The pictures/ photographs pasted on cardboards are placed in balloons, which are then inflated. The places of animals in the ecosystem are written on different cardboard boxes. The students grouped according to colors pop the balloons by sitting on them. Groups of students decide which ecosystem the animal shown on the picture/photograph in the balloon belongs to and continue on the track prepared with various hurdles. Students who reach the end of the track put the animal pictures/photographs in the relevant boxes on which the names of the ecosystems are written. At the end of the game, the correctly placed pictures/photographs in the boxes are counted according to the colors of the groups. The group which has placed the highest number of correct pictures/photographs wins.

When the activity finishes, the students are given the self-assessment form presented below and asked to evaluate the game. Using the Flip-Flop program, student works are compiled in an ebooklet and displayed in the electronic medium. 
5

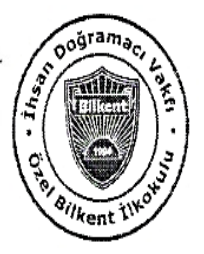

ADI SOYADI :

SINIFI:
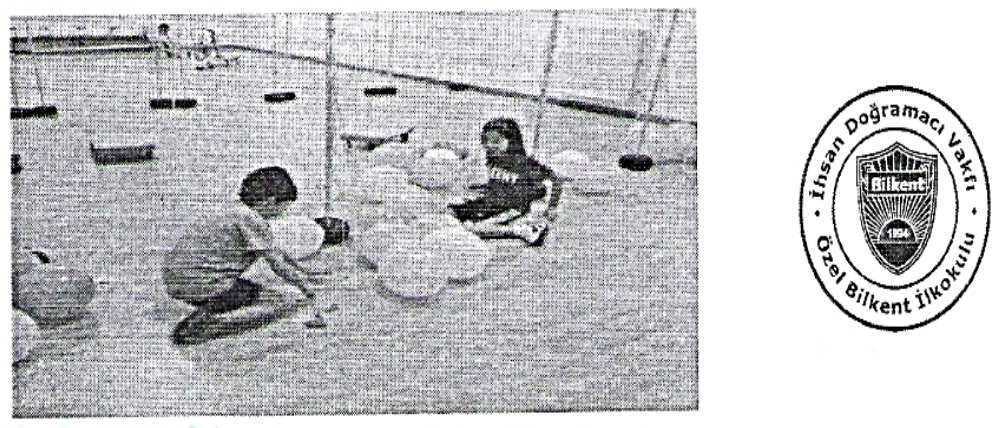

IHSAN DOĞRAMACI VAKFI ÖZEL BILKENT ILKOKULU

ÖĞRENCI ÖZ DEĞERLENDIRME FORMU

Sevgili öğrenciler,

Beden eğitimi dersinde yaptığınız "Engelleri Aş Bilgiye Ulaş "etkinliği ile ilgili öz değerlendirme yapabilmeniz için aşağıdaki boșlukları kendinize göre doldurunuz.

1. Bu çalışmada

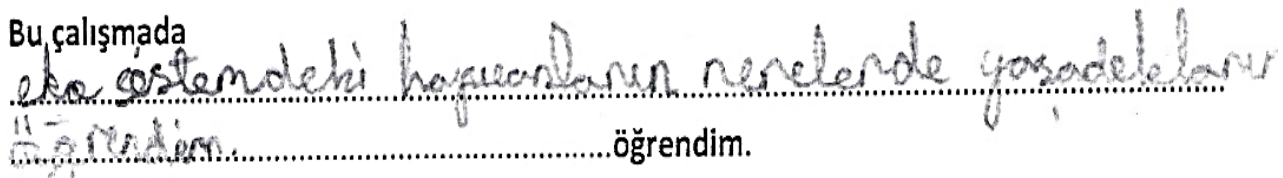

2. Bu çalışmada

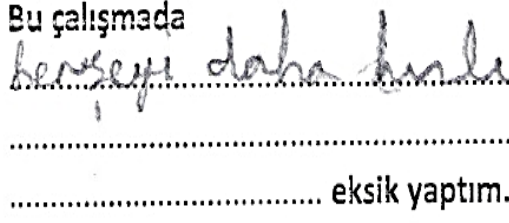

3. Bu çalışmada en iyi

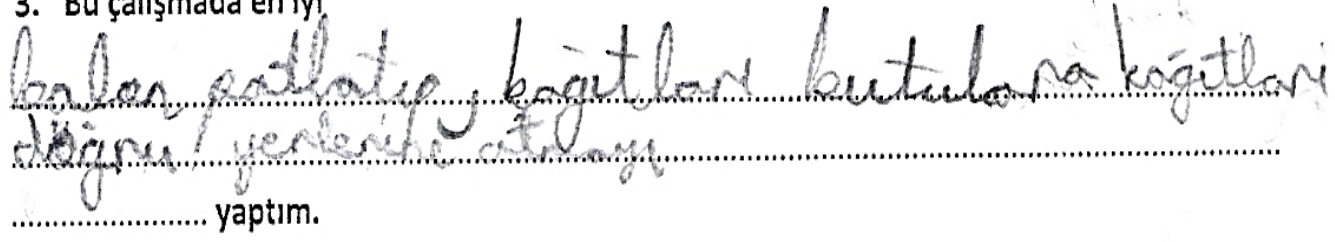

4. Bu çalışma sonunda

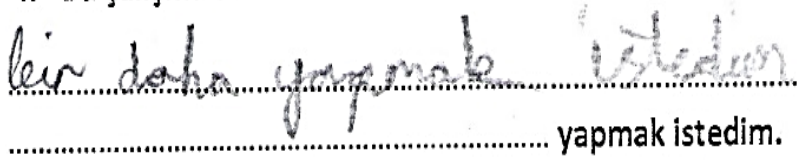


Çalışmayla ; kütüphane araştırmalarını daha keyifli yapan öğrenciler öğrendikleri bilgileri daha kolay transfer ederler.

\section{Young Architects at Work - Research - Learn - Apply}

The aim of the activity is to highlight the importance of research and the library by relating library lessons to visual arts lessons to support the PYP unit.

The life of the famous Spanish architect Antoni Gaudi is presented to Grade 2 students through visuals in the library. In the following library lessons, students are instructed to use books and the computer to learn more about Gaudi's works of architecture.

In the visual arts lessons, students discuss the differences between Gaudi's works and other works of architecture and are instructed to design their own houses. Designs are first drawn on paper and then converted to 3D models.

In the library lessons, students are asked to imagine and write down the story of people living in the houses they designed in a fairy tale spirit. After the activity finishes, the houses designed by the students are displayed to the school community.

\section{A Journey with a Book: Traveling with Hot Chocolate}

The activity aims to take students on a journey to learn about a city by raising their awareness through a book and to conduct a social responsibility project in cooperation with the Grade 6 Turkish language teacher.

The students have already been shown how a book can be a starting point for an activity in practice. Students read "Traveling with Hot Chocolate", a popular book by the author Sevim Ak, in the library hours and Turkish lessons. In the library lessons, students are asked to conduct research about the history of the bookmark and to find out what a bookplate (ex libris) is and how it originated. They listen to the presentation prepared by the librarian. After students finish reading the book, they are asked to prepare a bookmark, a bookplate and models that represent the theme of the book for their project. Turkish teacher asks the students to complete the workbook. In the meantime, the students and teachers at Tarsus American College, which was 
already contacted, also complete the same reading activity and other activities. The author of the book is invited to Ankara. From among the students in Tarsus, 14 students who were selected by teachers for their high performance come to Ankara to participate in the conversation with the author. They meet with the author and talk about the activities they completed in relation to the book. They also examine the works of the students in the school hosting them.

One month after the activity in Ankara, 14 students with the best performance are taken to Tarsus on a school trip. They examine the works students in Tarsus produced in relation to the book and view student presentations.

A social responsibility project related to the book title is launched. Students sell hot chocolate and coffee to other students in the school. The money collected is used to buy a laptop and a projector to a rural school in Çubuk district of Ankara, which had asked for help. A book donation campaign is organized across the school for the library of the rural school to be visited. A group of Grade 6 students visits the school. The visiting students give the books collected in the donation campaign to the library and the laptop and projector to the school principal. They present the book and the relevant activities they conducted to the students of the rural school.

\section{A Thousand Cranes and A Hope Project}

Inspired by Eleanor Coerr's book "Sadako and the Thousand Paper Cranes", the realities and consequences of war and the importance of hope and peace are emphasized, and a social responsibility project is launched.

All Grade 7 students read the book titled "Sadako and the Thousand Paper Cranes". They examine poetry and short story books about war and peace, hope and migration in the library. They are asked to write a poem or a short story following the example of a work they read and liked. The chorus formed with the help of the music teacher is trained to sing songs about war and peace.

International Association of School Librarianship

https://www.iasl-online.org/ 
Origami artist Nazan Tacer is invited to the school to teach students how to make a paper crane in the library. The paper cranes students have made are displayed in the library.

Grade 7 students present the "Thousand Cranes and A Hope" performance to the middle school students. Students give a theatrical performance of the songs, poems and stories they have learnt. In the context of the same project related to the book, a toy donation campaign is started in the school. A group of students deliver the collected toys to "The Association for Solidarity with Asylum Seekers and Migrants" to be given to migrants who flee the civil war in Syria.

\section{An Expressive Journey}

Based on the tale "The Town Musicians of Bremen", Grade 3 students examine literary genres like letter, interview, memoir, biography, autobiography and diary, and make presentations.

Students are asked to read the tale titled "The Town Musicians of Bremen". They analyze the characters. Then they are grouped to do research on letter, interview, memoir, biography, autobiography and diary genres. They use the encyclopedias, dictionaries and other books in the library in their research. Each group decides on a type of presentation like a power point presentation, poster presentation, etc., and prepares its presentation accordingly. They explain the relevant genre to their peers using the presentation type of their choice. The other groups listen to the presentations carefully and take notes. Then students are asked to individually write a piece exemplifying the genres studied and demonstrating empathy with the characters in the tale. The examples include diary of the dog, biography of the cat, etc. Students present their works to their peers and display them in the classroom corridor. The student products are then placed in the portfolios to be presented to the families.

\section{Bibliography}

Ak, S. (2010). Sıcak Çikolatalı Yolculuklar. İstanbul: Can Yayınları.

Coerr, E. (2010). Sadako : herşeye rağmen umudunu yitirmeyen Sadako'nun gerçek yaşam öyküsü. İstanbul: Beyaz Balina.

Grimm Kardeşler (2009). Bremen Mızıkacıları. İstanbul: Kelime Yayınları. 
Rodríguez, R. (2007). Building on nature : the life of Antoni Gaudí. New York: H.Holt.

International Association of School Librarianship https://www.iasl-online.org/ 